\title{
Microbiological Profile of Asyptomatic Bacteriuria in Pregnancy
}

\section{Anu Mary Bose*, Sreekumary PK and Sobha Kurian Pulikkottil}

Department of Microbiology, Government Medical College Kottayam, Kerala, India

${ }^{*}$ Corresponding author: Anu Mary Bose, Department of Microbiology, Government Medical College Kottayam, Kerala, India, Tel: + 919746559119; E-mail: doc_anubose@yahoo.co.in

Received date: October 07, 2016; Accepted date: October 20, 2016; Published date: October 30, 2016

Copyright: (C) 2016 Bose AM et al. This is an open-access article distributed under the terms of the Creative Commons Attribution License, which permits unrestricted use, distribution, and reproduction in any medium, provided the original author and source are credited.

Citation: Bose AM, Sreekumary PK, Pulikkottil SK. Microbiological profile of asyptomatic bacteriuria in pregnancy. Crit Care Obst\&Gyne. $2016,2: 26$.

\section{Abstract}

Background: Asymptomatic bacteriuria is the presence of actively multiplying bacteria within the urinary tract in the absence of any symptoms. Anatomical and physiological changes make women more susceptible to UTI in pregnancy.

Objectives: To determine the percentage of pregnant women with asymptomatic bacteriuria and its microbiological profile.

Methods: A total of 555 antenatal women who had no clinical features of urinary tract infection were recruited for this study over a period of one year. Clean catch mid-stream urine sample was collected and semi quantitatively cultured immediately. Significant bacteriuria was identified and antibiotic sensitivity found out by conventional methods.

Results: Significant growth was observed in 26 samples. There was no association between age, parity, gravidity, period of gestation and asymptomatic bacteriuria. Gram stain was found to be the best screening test. Escherichia coli was the commonest organism isolated. Escherichia coli and Staphylococcus saprophyticus were the most resistant organisms.

Conclusion: Escherichia coli, the most common organism isolated, was resistant to most of the commonly used antibiotics. Wet film examination, the most commonly used screening test in our set up, was less sensitive and specific. So, culture has to be done in all antenatal cases for screening asymptomatic bacteriuria of pregnancy.

Keywords: Asymptomatic bacteriuria; UTI; Pregnancy; Semiquantitative culture

\section{Introduction}

Urinary tract infections are the most common infections encountered in clinical practice. About $50 \%$ of women experience at least one episode of urinary tract infection during their life time [1]. UTI in pregnancy can be symptomatic or asymptomatic [1-4]. Asymptomatic bacteriuria (ASB) is defined as persistently and actively multiplying bacteria in significant numbers i.e., 105 bacteria per $\mathrm{ml}$ within the urinary tract without any obvious symptoms [1-5]. It is also known as Covert bacteriuria. Females are more susceptible for these infections because of the short length of urethra along with proximity to warm, moist anal canal [4]. Sexual intercourse facilitates the ascent of bacteria into bladder. The pregnant females are two times more commonly affected than age matched non pregnant females. The reason behind this is urinary stasis due to progesterone effect in pregnancy in addition to different anatomical changes occurring during pregnancy $[2,4]$. Various studies from the west have documented the prevalence of asymptomatic bacteriuria in pregnancy to be between 2 and $7 \%$ $[6,7]$ while in India it was found to be on higher side i.e., between 5 and 17\% [8-10]. Studies in African region showed higher prevalence than both these regions $[11,12]$. Commonest organisms responsible are Escherichia coli (80-85\%), followed by coagulase negative Staphylococcus spp., Klebsiella spp., Pseudomonas spp., and Proteus spp. [6-9,11,12].

The Gold standard investigation for detection of asymptomatic bacteriuria is urine culture $[1-3,7,13]$. Therefore, urine culture at first prenatal visit or between 12 and 16 weeks of gestation should be considered as a screening test of choice $[1,2]$. Detection of asymptomatic bacteriuria during pregnancy is important as subsequently it may lead to symptomatic infection during that pregnancy in $25 \%$ of infected women, chronic infection resistant to chemotherapy, pyelonephritis, low birth weight (LBW) babies and preterm delivery $[9,10,14]$. This study is designed to determine the bacterial profile and antibiotic susceptibility pattern of uropathogen among pregnant women, along with the outcome of urinary tract infection in pregnancy.

\section{Objectives}

- To find out the percentage of women with asymptomatic bacteriuria in pregnancy, coming to Obstetrics OPD in Government Medical College, Kottayam.

- To find out the common isolates and their antibiotic sensitivity pattern. 


\section{Methodology}

\section{Study design}

Descriptive study.

\section{Study setting}

Department of Microbiology, Government Medical College, Kottayam and Department of Obstetrics and Gynaecology, Government Medical College, Kottayam.

\section{Duration of study}

One year from February 2014.

\section{Study population}

Antenatal women who attended Obstetrics OPD during 12-16 weeks of pregnancy or for first time during whole pregnancy [15-17].

\section{Inclusion criteria}

Asymptomatic pregnant females who were willing to participate in study.

\section{Exclusion criteria}

Those with signs and symptoms of UTI, those with diabetes, those with any structural anomalies of urinary tract, those patients who took antibiotics in past one week and those who were not willing to participate were excluded from this study.

\section{Sample size}

550 -Is the minimum sample size calculated. Formula used was $4 p q / d^{2}$.

Prevalence $p=15, d=20 \%$ of $p$

\section{Sampling methodology}

Non probability convenient sampling.

\section{Sample collection and processing}

The study was conducted after obtaining necessary permission from institutional ethics committee. A total of 555 asymptomatic pregnant women at their first visit in whole pregnancy or during 12-16 weeks of pregnancy was taken into consideration [15-17]. Study period was one year from February 2014. Informed consent was taken. The subjects were instructed how to collect clean catch mid-stream urine sample. The samples were taken in sterile leak proof universal containers and immediately transferred to laboratory and processed within 2 hours of collection.

Samples were subjected to macroscopic examination, wet film examination for pyuria, Gram stain, catalase test, nitrate reductase (Griess) test and semiquantitative culture method. The semiquantitative culture was done by surface streaking method on 5\% sheep Blood agar, Cysteine Lactose Electrolyte Deficient agar with bromo-thymol blue and MacConkey agar. HiCrome UTI agar and HiCrome Strep B Selective Agar (both by Hi Media Laboratories, Mumbai) was also used to aid in early identification of isolates with significant bacteriuria. For the inoculation, sterile standard nichrome wire loop, with volume holding capacity of $0.001 \mathrm{ml}$ was used. The plates were incubated at $37^{\circ} \mathrm{C}$ for 24 hours.

HiCrome UTI agar: Media is prepared as per manufacturer's instructions. Sample was inoculated and incubated at $37^{\circ} \mathrm{C}$ overnight. Differentiation is aided by different colour of different bacteria like E.coli $\rightarrow$ dark pink to reddish, Proteus $\rightarrow$ brown halo, Klebsiella, Enterobacter and Serratia $\rightarrow$ metallic blue, S.aureus $\rightarrow$ golden, opaque, small, Citrobacter $\rightarrow$ metallic blue with red halo, S.saprophyticus $\rightarrow$ pink, opaque, small, Candida albicans $\rightarrow$ colourless, Streptococcus agalactiae $\rightarrow$ Light blue, Pseudomonas aeruginosa $\rightarrow$ Translucent, cream to blue.

HiCrome strep B selective agar: Media was prepared according to manufacturer's instructions. Blue coloured colonies with luxuriant growth of Streptococcus agalactiae was observed after incubation at $37^{\circ} \mathrm{C}$ overnight.

\section{Screening Tests}

\section{Wet film examination of uncentrifuged urine for pyuria}

A $0.05 \mathrm{ml}(50 \mu \mathrm{l})$ of uncentrifuged well mixed urine sample was transferred carefully on to the middle of a slide. A coverslip, $22 \times 22 \mathrm{~mm}$ was applied immediately avoiding trapped bubbles so that the film should show a small excess of fluid along the edges of the coverslip. The prepared film was examined under microscope in high power field. The finding of more than 1 leukocyte per 7 high power fields corresponds with more than 104 leukocytes per $\mathrm{ml}$, which was considered as significant pyuria $[18,19]$.

\section{Gram stain of well mixed uncentrifuged urine for microorganisms}

A drop of well mixed urine is allowed to air dry, the smear is fixed, stained and examined under oil immersion (1000X) [3]. The presence of at least one bacterium per oil immersion field in a midstream, clean-catch, uncentrifuged, Gram-stained, urine correlates with $10^{5}$ bacteria per $\mathrm{ml}$ of urine or more. Smear is discarded as negative only after examining at least 20 oil immersion fields $[4,9,20]$.

\section{Urinary nitrite detection}

Urinary nitrite is detected by adding $1.0 \mathrm{ml}$ of urine to $1.0 \mathrm{ml}$ of Griess reagent in a clean test tube. The Griess reagent was prepared by dissolving $1.5 \mathrm{gm}$ of sulphanillic acid in $450 \mathrm{ml}$ of $10 \%$ aceticacid. This was then added to a solution of $0.6 \mathrm{gm}$ of $\propto$-naphthylamine dissolved in $60 \mathrm{ml}$ of boiling distilled water. The reagent remains stable for several months when stored in a stopper amber bottle and refrigerated. 
Deterioration of the test reagent is detected by the development of a pink colour. If pink color develops; reagent can be regenerated by shaking it vigorously with small amounts of metallic zinc powder and filtering it.

The immediate development of a pink colour to dark red colour indicates the presence of nitrites in urine and is called a positive reaction. The $\propto$-naphthylamine was handled carefully because of its possible hazards [21,22].

\section{Urinary catalase detection}

1.5 to $2 \mathrm{ml}$ of uncentrifuged well mixed urine sample was placed in a test tube. Four drops of $10 \%$ hydrogen peroxide was added to the test tube, and the mixture was shaken gently for 5 seconds.

A positive finding was defined as the formation of effervescence sufficient to form a complete ring or layer on the surface of the liquid within 1 to 2 minutes of the addition of the hydrogen peroxide. The test result was considered negative in the absence of effervescence or when the ring of effervescence was incomplete after two minutes $[9,23,24]$.

All these screening tests were evaluated for its accuracy by calculating sensitivity, specificity, positive predictive value and negative predictive value [25].

\section{Definitions and Formulae}

- True Positive (TP): Screening test and culture, both positive

- False Positive (FP): Positive screening test finding and negative culture

- True Negative (TN): Screening test and culture, both negative

- False Negative (FN): Screening test negative and culture positive

- Sensitivity=TP/(TP+FN): Probability that screening test will be positive in patients with UTIs (positive culture)

- Specificity=TN/(TN+FP): Probability that screening test will be negative in patients without UTIs (negative culture)

- Positive Predictive Value (PPV) [TP/(TP+FP)]: Probability that a UTI is present when screening test is positive.

- Negative Predictive Value (NPV) [TN/(TN+FN)]: Probability that a UTI is not present when screening test is negative.

\section{Semi Quantitative Culture of Urine}

After mixing urine thoroughly the calibrated loop was introduced vertically into the urine and taken out. Loop was touched to the center of the plate, from which the inoculum was spread in a line across the plate. Without flaming or re-entering urine, loop was drawn across the entire plate, crossing the first inoculum streak numerous times to produce isolated colonies. Plates were incubated at $37^{\circ} \mathrm{C}$ for 24 hours. Number of colonies were counted and multiplied by 1000 to get the colony count [3].

\section{Interpretation}

- No bacteriuria-If no growth was present.

- No significant bacteriuria-If the colony count was $<10^{5}$ colony-forming units/ml.

- Significant bacteriuria-If colony count was $>10^{5}$ colonyforming units $/ \mathrm{ml}$ of a particular organism except in case of growth of gram-positive cocci where even 102 cfus per ml were taken as significant.

\section{Antibiotic Sensitivity Testing of Bacterial Isolates}

Antibiotic sensitivity testing was done using Kirby-Bauer method (disc diffusion), with 0.5 McFarland standard turbidity of the inoculum on blood agar for Streptococcus spp. and MuellerHinton agar for other isolates. Standardization of antibiotic susceptibility testing was done by using standard strains of Escherichia coli - ATCC 25922, Enterococcus faecalis-ATCC 29212 and Staphylococcus aureus-ATCC 25923 as control strains. E-test, Vitek 2 systems and agar dilution was done to detect the MIC of Vancomycin for all Staphylococcus spp. Antibiotics were tested and zone of inhibition of growth was measured and interpreted according to CLSI guidelines [26]. All antibiotics were not reported. Only antibiotics which can be safely given in pregnancy and those which attain good urinary concentration were reported. Antibiotics which can be given orally were preferred for reporting. Antibiotics reported were Ampicillin, Amoxicillin-clavulanic acid, Cephalosporin 1st generation (Cephalexin), Cephalosporin 3rd generation (Cefotaxime), Cotrimoxazole (Trimethoprim/Sulphamethoxazole), Norfloxacin, Nitrofurantoin and Ciprofloxacin [27] depending upon the isolates. Test for ESBL production was also done for relevant isolates. The data was numerically coded and was entered in Microsoft excel spread sheet. Further analysis was done using the software SPSS 16 and tables and charts were created using excel.

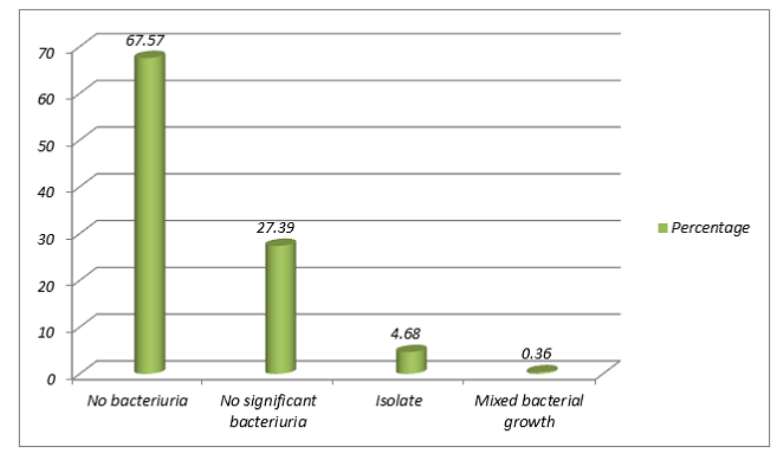

Figure 1 Graph showing report of all the samples studied. 


\section{Results}

As per the inclusion and exclusion criteria, mid-stream clean catch urine sample was collected from 555 asymptomatic pregnant females.

Out of the total 555 subjects, 26 (4.68\%) were having asymptomatic bacteriuria of pregnancy (Figure 1). Most common age group affected was $26-30$ years followed by $21-25$ years and 31-35 years (Figure 2). ASB was more common among primi gravida (53.85\%) followed by gravida 2 (30.77\%). Parity wise distribution of ASB was as follows: nulli para (57.69\%)>para $1(30.77 \%)>$ para $2(7.69 \%)>$ para $3(3.85 \%)$. Maximum case of ASB was reported during 5-10 weeks (50\%) followed by $10-15$ weeks (26.92\%) (Figure 3).

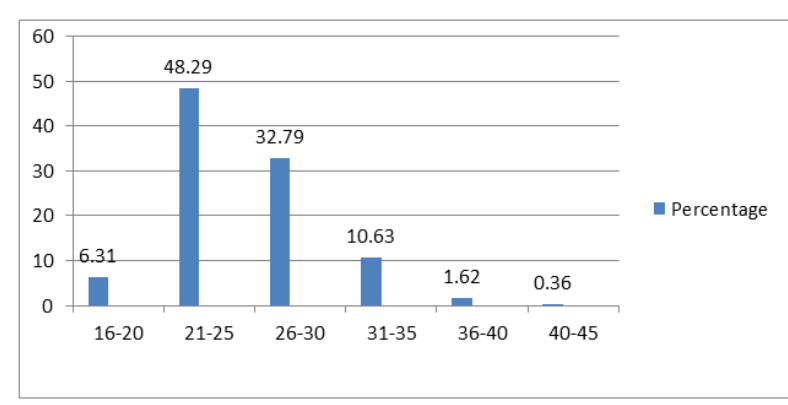

Figure 2 Graph of age distribution.

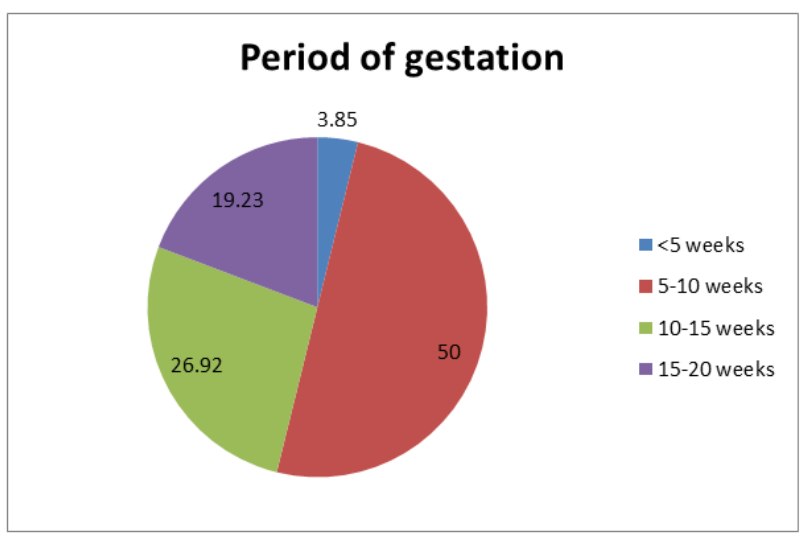

Figure 3 Graph of period of gestation wise distribution of those with ASB.

Out of the 26 cases with asymptomatic bacteriuria of pregnancy, $23(88.46 \%)$ were not having any risk factors. Only 2 (7.69\%) cases had associated UTI (before pregnancy or during previous pregnancy) and one (3.85\%) had UTI in early period of present pregnancy. So overall a $10 \%$ of subjects were having history of UTI. Sensitivity, specificity, positive predictive value and negative predictive value of the screening tests are shown in Table 1. Out of the 26 samples which were having ASB,
15(57.7\%) were gram negative bacteria, 10 (38.5\%) were gram positive bacteria and one (3.8\%) was yeast. Most common isolate was Escherichia coli followed by K.pneumoniae, Staphylococcus saprophyticus, Streptococcus agalactiae, Citrobacter koseri, Staphylococcus aureus, Enterococcus faecalis and Candida tropicalis respectively (Table 2). Antibiotic sensitivity of the isolates is shown in Tables $\mathbf{3}$ and $\mathbf{4}$.

Table 1 Sensitivity, Specificity, Positive predictive and negative predictive value of screening tests.

\begin{tabular}{|l|l|l|l|l|}
\hline & $\begin{array}{l}\text { Wet film } \\
\text { for } \\
\text { pyuria }\end{array}$ & $\begin{array}{l}\text { Gram } \\
\text { stain }\end{array}$ & $\begin{array}{l}\text { Urinary } \\
\text { catalase }\end{array}$ & $\begin{array}{c}\text { Urinary } \\
\text { nitrite }\end{array}$ \\
\hline True positives & 173 & 168 & 144 & 13 \\
\hline False negative & 7 & 10 & 36 & 167 \\
\hline True negative & 268 & 374 & 375 & 375 \\
\hline False positive & 107 & 1 & 0 & 0 \\
\hline Sensitivity & $86.50 \%$ & $94.38 \%$ & $80.00 \%$ & $7.20 \%$ \\
\hline Specificity & $71.40 \%$ & $99.73 \%$ & $100 \%$ & $100 \%$ \\
\hline Positive predictive value & $60.20 \%$ & $99.40 \%$ & $100 \%$ & $100 \%$ \\
\hline $\begin{array}{l}\text { Negative predictive } \\
\text { value }\end{array}$ & $97.40 \%$ & $99.70 \%$ & $93.50 \%$ & $84.80 \%$ \\
\hline
\end{tabular}

Table 2 Microbiological profile of asymptomatic bacteriuria.

\begin{tabular}{|l|l|l|}
\hline Isolate & Number & Percentage \\
\hline E.coli & 7 & 26.92 \\
\hline K.pneumoniae & 6 & 23.08 \\
\hline Citrobacter koseri & 2 & 7.69 \\
\hline Staphylococcus aureus & 2 & 7.69 \\
\hline $\begin{array}{l}\text { Methicillin resistant coagulase negative } \\
\text { Staphylococci (MRCoNS) }\end{array}$ & 3 & 11.54 \\
\hline Enterococcus faecalis & 2 & 7.69 \\
\hline Candida tropicalis & 1 & 3.85 \\
\hline Streptococcus agalactiae & 3 & 11.54 \\
\hline Total & 26 & 100.00 \\
\hline
\end{tabular}

\section{Discussion}

A one year study was conducted on microbiological profile of asymptomatic bacteriuria in pregnancy in Government Medical College, Kottayam. A total of 555 samples were studied. Significant bacteriuria was noted in $26(4.68 \%)$ isolates. The low percentage of asymptomatic bacteriuria may be attributed to the good antenatal care, hygiene and awareness among people of Kerala. The prevalence of asymptomatic bacteriuria in the following studies were similar to this study-Lata R. Chandel et al. [8] from Shimla (7.34\%), Jayalakshmi et al. [28] from Bangalore 
(7.4\%), Jennifer Perera et al. [29] from Srilanka (3.6\%) and Morike Ngoe Mokube et al. [30] from Cameroon (7.8\%).

Table 3 Sensitivity of gram positive isolates.

\begin{tabular}{|c|c|c|c|c|}
\hline Drugs tested & Staphylococcus aureus & $\begin{array}{ll}\text { Methicillin } & \text { resistant } \\
\text { coagulase } & \text { negative } \\
\text { Staphylococci } & \end{array}$ & Enterococcus faecalis & Streptococcus agalactiae \\
\hline \multirow{2}{*}{ Ampicillin } & 0 & 0 & 2 & 3 \\
\hline & $0 \%$ & $0 \%$ & $-20 \%$ & $-30 \%$ \\
\hline \multirow{2}{*}{ Gentamicin } & 1 & 1 & 0 & 0 \\
\hline & $-10 \%$ & $-10 \%$ & $0 \%$ & $0 \%$ \\
\hline \multirow{2}{*}{ Erythromycin } & 1-NR & $0-N R$ & 2-NR & 3-NR \\
\hline & $-10 \%$ & $0 \%$ & $-20 \%$ & $-30 \%$ \\
\hline \multirow{2}{*}{ Cephalexin } & 2 & 0 & $0-N R$ & 3 \\
\hline & $-20 \%$ & $0 \%$ & $0 \%$ & $-30 \%$ \\
\hline \multirow{2}{*}{ Amikacin } & 2 & 3 & 0 & 0 \\
\hline & $-20 \%$ & $-30 \%$ & $0 \%$ & $0 \%$ \\
\hline \multirow{2}{*}{ Vancomycin } & 2 & 3 & 2 & 3 \\
\hline & $-20 \%$ & $-30 \%$ & $-20 \%$ & $-30 \%$ \\
\hline \multirow{2}{*}{ Cloxacillin } & 2 & 0 & \multirow{2}{*}{ NT } & \multirow{2}{*}{ NT } \\
\hline & $-20 \%$ & $0 \%$ & & \\
\hline \multirow{2}{*}{ Mox-Clav } & 1 & 0 & 2 & 2 \\
\hline & $-10 \%$ & $0 \%$ & $-20 \%$ & $-20 \%$ \\
\hline \multirow{2}{*}{ Linezolid } & 2-NR & 3-NR & 2-NR & 2-NR \\
\hline & $-20 \%$ & $-30 \%$ & $-20 \%$ & $-20 \%$ \\
\hline
\end{tabular}

Table 4 Sensitivity of gram negative isolates.

\begin{tabular}{|c|c|c|c|}
\hline Drugs & Escherichia coli & Klebsiella pneumoniae & Citrobacter koseri \\
\hline Ampicillin & $\begin{array}{l}1 \\
(6.25 \%)\end{array}$ & 0 & 0 \\
\hline Gentamicin & $\begin{array}{l}6 \\
(37.5 \%)\end{array}$ & $\begin{array}{l}6 \\
(37.5 \%)\end{array}$ & $\begin{array}{l}2 \\
(12.5 \%)\end{array}$ \\
\hline Cephalexin & $\begin{array}{l}3 \\
(18.75 \%)\end{array}$ & $\begin{array}{l}5 \\
(31.25 \%)\end{array}$ & 0 \\
\hline Amikacin & $\begin{array}{l}6 \\
(37.5 \%)\end{array}$ & $\begin{array}{l}6 \\
(37.5 \%)\end{array}$ & $\begin{array}{l}2 \\
(12.5 \%)\end{array}$ \\
\hline Cefotaxime & $\begin{array}{l}5 \\
(31.25 \%)\end{array}$ & $\begin{array}{l}6 \\
(37.5 \%)\end{array}$ & $\begin{array}{l}2 \\
(12.5 \%)\end{array}$ \\
\hline Cotrimoxazole & $\begin{array}{l}3 \\
(18.75 \%)\end{array}$ & $\begin{array}{l}5 \\
(31.25 \%)\end{array}$ & $\begin{array}{l}2 \\
(12.5 \%)\end{array}$ \\
\hline Ciprofloxacin & $\begin{array}{l}4 \\
(25 \%)\end{array}$ & $\begin{array}{l}6 \\
(37.5 \%)\end{array}$ & $\begin{array}{l}2 \\
(12.5 \%)\end{array}$ \\
\hline Cefoperazone-sulbactum & 7 & 6 & 2 \\
\hline
\end{tabular}




\begin{tabular}{|l|l|l|l|}
\hline & $(43.75 \%)$ & $(37.5 \%)$ & $(12.5 \%)$ \\
\hline \multirow{3}{*}{ Piperacillin- tazobactum } & 7 & 6 & 2 \\
\hline \multirow{3}{*}{ Meropenem } & $(43.75 \%)$ & $(37.5 \%)$ & $(12.5 \%)$ \\
\hline \multirow{3}{*}{ Norfloxacin } & 7 & 6 & 2 \\
\hline \multirow{3}{*}{ Nitrofurantoin } & $(43.75 \%)$ & $(37.5 \%)$ & $(12.5 \%)$ \\
\hline & 4 & 5 & 2 \\
Imipenem & $(25 \%)$ & $(31.25 \%)$ & $(12.5 \%)$ \\
\hline \multirow{3}{*}{ Mox-Clav } & 5 & 3 & \\
\hline
\end{tabular}

Highest number of pregnant females with asymptomatic bacteriuria was noted in age group 26-30 years (30.77\%) followed by 21-25 years and 31-35 years (both 26.92\%). The youngest among those studied was 18 years and oldest 45 years. Similar results were obtained in study conducted by Ananthi Kasinathan et al. [31] from Pondicherry in 2014, with maximum subjects with ASB in the age group of 26-30 years. Many studies show advancing age as a risk factor for acquiring $A S B$ in pregnancy because there is decrease in glycogen deposition and reduction in the lactobacillus as a part of ageing process which enhances bacterial adherence and invasion by pathogens and make them more susceptible [32].

Asymptomatic bacteriuria in pregnancy was more common among primigravidae $(53.85 \%)$ compared to multigravidae. The findings were correlating with the findings of Sudha Kerure et al. [33] from Karnataka (2012).

In those subjects with asymptomatic bacteriuria in pregnancy, $15 / 26(57.69 \%)$ were nulliparous women and $8 / 26$ (30.77\%) were para 1. A study by Lavanya and Jogalakshmi [9] from India and Ajayi et al. [34] in Nigeria also gave similar results.

Samples were taken at the first antenatal visit or during 12-16 weeks of pregnancy, based on different studies [35-37]. Maximum number of asymptomatic bacteriuria was detected in $5-10$ weeks of gestation (50\%) followed by $10-15$ weeks (26.92\%) and $15-20$ weeks (19.23\%). This finding was correlating with the finding of another study conducted by Lata R. Chandel et al. [8] from Shimla (2006).

Overall $10 \%$ of subjects with ASB had previous history of urinary tract infection. According to a study by Agersew Alemu et al. [10] (2011) from Ethiopia, 47 (12.2\%) of study subjects had history of urinary tract infection.

According to this study, Gram stain was the most sensitive test, i.e. there is high probability that Gram stain will be positive in those with asymptomatic bacteriuria of pregnancy. Gram stain also gives immediate information about the nature of infecting organism and helps to guide in empirical antimicrobial therapy. Urinary catalase, urinary nitrite and Gram stain were highly specific according to this study. That means there is high probability that urinary catalase, nitrite and Gram stain will be negative in subjects without asymptomatic bacteriuria of pregnancy. Urinary catalase, urinary nitrite and Gram stain were also having a high positive predictive value which means in a subject with asymptomatic bacteriuria of pregnancy there is high chance that these tests will be positive. Gram stain was having the highest negative predictive value followed by wet film for pyuria which means in a subject without asymptomatic bacteriuria of pregnancy there is high chance that these tests will be negative.

Gram stain examination was having similar sensitivity (96.0\%), specificity (99.2\%), positive predictive value (97.6\%) and negative predictive value (98.7\%) according to a study conducted by Celso Lui'Z Cardoso et al. [38] from Brazil (2006). Another study conducted by Taneja et al. [39] showed sensitivity, specificity, positive predictive value and negative predictive value of wet film examination for pyuria to be $68.4 \%$, $60.8 \%, 32.7 \%$ and $87.3 \%$ respectively. As there was no consensus in the methods used and the criteria for significant pyuria different tests showed different values on analysis as a screening test. According to a study conducted by Willy Fred Nabbugodi et al. [40] sensitivity (67.5\%), specificity (88.2\%), positive predictive value (67.5\%) and negative predictive value (88.2\%) was similar to our study for wet film examination. According to Morike Ngoe Mokube et al. [30] from Cameroon, sensitivity, specificity, positive predictive value and negative predictive value of urinary (Griess) nitrite test were respectively $8 \%, 98.7 \%, 67 \%$ and $77.8 \%$. The lower sensitivity of nitrite tests compared to previous reports may be due to the fact that this test is more accurate when the first voided specimen is collected or when urine has been stored in bladder for over four hours. It was difficult to ensure such conditions in our study. The presence of abnormal amounts of urobilinogen and ascorbic acid in urine as well as a urinary $\mathrm{pH}$ of $<6$ and bacteriuria due to gram-positive cocci or non-fermentative bacilli, such as Pseudomonas spp. account for some of the false-negative results $[24,41]$. False negatives can also occur when the organism present does not produce nitrate reductase and when dietary nitrate is absent [30]. Modified Griess nitrite test which needs incubation of urinary sediment in potassium nitrate may 
increase the specificity of the test. Catalase test was having similar sensitivity (83\%) in a study conducted by Stephen A. Berger et al. [41] from Israel and Shilpa et al. [20] from Bangalore, India. Many organisms causing urinary tract infection contain the enzyme catalase. The presence of catalase may be due to bacteria, but also to erythrocytes, WBC, or kidney cells. Therefore, this test is not specific for bacteria [42]. But in this study no false positivity was recorded for catalase reaction. This may be because of decreased number of WBC's and reduced immune response in asymptomatic bacteriuria of pregnancy. Catalase can also be false negative for catalase negative organisms and yeasts which were present in our study.

Out of the 26 samples with significant growth, 15 were gramnegative bacteria (57.7\%), 10 were gram-positive bacteria (38.5\%) and one was fungi (3.80\%). Escherichia coli was the most common organism isolated $(57.7 \%)$, followed by Klebsiella pneumoniae sub spp. pneumoniae $(23.08 \%)$, Staphylococcus saprophyticus and Streptococcus agalactiae (both 11.54\%), Citrobacter koseri, Staphylococcus aureus and Enterococcus faecalis (7.69\% each) and Candida tropicalis (3.85\%). Most studies report Escherichia coli as the most common organism isolated followed by Klebsiella spp. According to a study conducted by Gayathree et al. [43] from Hassan, Karnataka (2009), Escherichia coli emerged as the most frequent cause of ASB with 32 cases (51.61\%), followed by Proteus mirabilis with 9 cases (14.51\%), Staphylococcus aureus and Klebsiella pneumonia with 6 cases $(9.67 \%)$ each, Acinetobacter spp., with 5 cases (8.05\%), Pseudomonas aeruginosa with 3 cases $(4.83 \%)$ and Enterococcus faecalis with one case (1.61\%) [43]. According to a study by Madhu Udawat et al. [44] in India (2013), there was an increasing trend in the prevalence of S.aureus infection (15.28\%). This dramatic increase in prevalence rate can be attributed to the emergence and global spread of Staphylococcus aureus. Hence, recognizing this change in the spectrum of uropathogens remains important to guide changes in empirical antimicrobial therapy. According to Nithyasree et al. [45] from Tamilnadu (2013), majority of isolates were gramnegative bacteria (81.39\%). Gram-positive organisms were responsible only for $18.6 \%$. E.coli $(65.11 \%)$ was the most prevalent uropathogen isolated followed by Klebsiella pneumonia and Staphylococcus aureus which accounted $11.62 \%$ each. The least prevalent bacteria isolated were Proteus mirabilis (4.65\%).

Staphylococcus aureus isolates were $100 \%$ sensitive to Cephalosporin 1st generation drugs (Cephalexin). None of the Staphylococcus spp. was sensitive to Ampicillin and Nitrofurantoin. $50 \%$ of Staphylococcus aureus strains were sensitive to Amoxicillin-Clavulanic acid. Staphylococcus saprophyticus was $100 \%$ sensitive to Amoxicillin-Clavulanic acid but none were sensitive to first generation Cephalosporins. Enterococcus faecalis and Streptococcus agalactiae was $100 \%$ sensitive to Ampicillin. All the Enterococci were sensitive to Amoxycillin-Clavulanic acid. Streptococcus agalactiae strains were $100 \%$ sensitive to Cephalexin, Clindamycin and Amoxycillin-Clavulanic acid. As Streptococcus agalactiae strain was Erythromycin sensitive no inducible Clindamycin resistance was tested and Clindamycin was reported as sensitive for intra partum prophylaxis.
Escherichia coli isolates had more resistance rates than other gram-negative isolates. E.coli isolates were $100 \%$ sensitive only to third generation injectable drugs like CefoperazoneSulbactum, Piperacillin-Tazobactum, Meropenem and Imipenem. Ampicillin was the least sensitive drug (14.29\%) followed by Cephalexin (42.86\%), Cotrimoxazole (42.86\%), Norfloxacin (42.86\%) and Amoxicillin-Clavulanic acid (42.86\%). Ciprofloxacin was $57.14 \%$ sensitive, Cefotaxime and Nitrofurantoin (both $71.43 \%$ ) and aminoglycosides (85.71\%). For the two Cefotaxime resistant strains, ESBL production was tested and was found to be negative. Klebsiella spp. was $100 \%$ sensitive to aminoglycosides, Cefotaxime, Ciprofloxacin and all the third generation injectable drugs like Cefoperazone-Sulbactum, Piperacillin-Tazobactum, Meropenem and Imipenem. Cephalexin, Cotrimoxazole, Norfloxacin and AmoxicillinClavulanic acid was $83.33 \%$ sensitive. Nitrofurantoin was the least sensitive drug (50\%). None of Citrobacter koseri strains were sensitive to Cephalexin, Nitrofurantoin and AmoxicillinClavulanic acid. It was $100 \%$ sensitive to aminoglycosides, third generation Cephalosporins, Cotrimoxazole, fluoroquinolones and higher generaion injectables.

According to Chidre Yogiraj Vaijanathrao et al. [46] from Hyderabad, highest sensitivity was noted to Ciprofloxacin, Gentamicin, Nitrofurantoin, Ofloxacin and Amikacin. For grampositive cocci, highest sensitivity was seen with Amoxyclav, Nitrofurantoin and increasing resistance pattern were seen with Cephalosporins and Ampicillin. In a study by Amete Mihret Teshale et al. [47] from Ethiopia (2015), Nitrofurantoin, Clindamycin and Ciprofloxacin were the most effective antibiotics for gram-positive isolates with less efficacy of Sulfamethoxazole/Trimethoprim for these bacteria. Gentamicin, Amoxicillin-Clavulanic acid, Norfloxacin and Ciprofloxacin were the antibiotics of choice for gram-negative isolates.

Prompt report was given to the physician as soon as we detect a case of ASB. Patients were also informed about the need to take treatment. All of the patients complied with treatment.

\section{Limitations}

Molecular methods for identification were not done.

\section{Conclusion}

The percentage of asymptomatic bacteriuria of pregnancy is less towards this part of the country. The probable reason could be the prompt antenatal care and good hygienic living of people. Gram stain was found to be the best screening test with high sensitivity and specificity. In our set up urine microscopy is the one that is given importance in antenatal screening. If the wet film is positive, then only a sample is sending for culture. But as wet film examination is not having a good sensitivity and specificity according to this study and many other studies, urine culture should always be done as recommended by standard guidelines ideally between 12-16 weeks of pregnancy to detect asymptomatic bacteriuria and to decrease morbidity to mother and foetus. Gram-negative bacteria were isolated from more than half of the samples. Escherichia coli was the most common 
organism isolated closely followed by Klebsiella spp. Grampositive bacteria including Group B Streptococci were also isolated in large numbers. Even though pregnancy is considered as an immunocompromised condition, only one Candida isolate was obtained until this period of gestation. Staphylcoccus aureus strains were $100 \%$ sensitive to Cephalexin and all the Staphylococcus saprophyticus strains were sensitive to Amoxycillin-Clavulanic acid. All the Streptococci were sensitive to Ampicillin. Escherichia coli, the most common organism isolated, was comparatively resistant to the most common antibiotics used like Ampicillin and Cephalexin. Cefotaxime was found to be the best drug which can be used against gramnegative bacteria. Nitrofurantoin was another oral formulation found to be useful for Escherichia coli. But Nitrofurantoin was not that effective for other gram-negative bacilli. Resistance to Ciprofloxacin, Norfloxacin, Ampicillin, Cephalexin and Amoxicillin-Clavulanic acid could have been contributed by an increase in prescribing practices of these drugs for uncomplicated UTI and other indications in recent years. Complications of asymptomatic bacteriuria like preterm labor and low birth weight were almost not detected in this study. This may be due to the prompt treatment and good antenatal care.

\section{References}

1. Leslie C, Albert B, Max S (1998) Topley and Wilson's Microbiology and Microbial Infections. (10th edn), Edward Arnold, London.

2. Cunningham FG, Gant NF, Laveno KJ (2014) Renal and urinary tract disorders, Williams Obstetrics. (24th edn), McGraw-Hill Medical Publishing Division, New York.

3. Forbes BA, Sahm DF, Alice S (2007) Infections of Urinary Tract, Bailey \& Scott's Diagnostic microbiology. (12th edn), Weissfeld, Mosby Elsevier, Missouri.

4. Mandell GL, Bennett JE, Dolin R (2009) Urinary Tract Infections. Mandell, Douglas and Bennett's Principles and Practice of Infectious Diseases (7th edn).

5. Anantnarayanan R, Paniker J (2013) Ananthanarayanan and Paniker's text book of Microbiology (9th edn).

6. Imade PE, Izekor PE, Eghafona NO, Enabulele OI, Ophori E (2010) Asymptomatic bacteriuria among pregnant women. North Am J Med Sci 2: 263-266.

7. Colgan R, Nicolle LE, Mcglone A, Hooton TM (2006) Asymptomatic Bacteriuria in Adults. American Family Physician 74: 985-990.

8. Chandel LR, Kanga A, Thakkur K, Mokta KK, Sood A, et al. (2012) Prevalance of Pregnancy Associated Asymptomatic Bacteriuria: A Study Done in a Tertiary Care Hospital. J Obstet Gynaecol India 62: 511-514.

9. Lavanya SV, Jogalakshmi D (2002) Asymptomatic bacteriuria in antenatal women. Indian J Med Microbiol 20: 105-106.

10. Jain V, Das V, Agarwal A, Pandey A (2013) Asymptomatic bacteriuria \& obstetric outcome following treatment in early versus late pregnancy in north Indian women. Indian J Med Res 137: 753-758.

11. Alemu A, Moges F, Shiferaw Y, Tafess K, Kassu A, et al. (2012) Bacterial profile and drug susceptibility pattern of urinary tract infection in pregnant women at University of Gondar Teaching Hospital, Northwest Ethiopia. BMC research notes 5: 197.
12. Demilie T, Beyene G, Melaku S, Tsegaye W (2012) Urinary Bacterial Profile and Antibiotic Susceptibility Pattern among Pregnant Women in North West Ethiopia. Ethiopian Journal of Health Sciences 22: 121-128.

13. Nicolle LE (2015) Screening for Asymptomatic Bacteriuria in Pregnancy. J Obstet Gynaecol Can.

14. Nicolle LE, Bradley S, Colgan R, Rice JC, Schaeffer A, et al. (2005) Infectious Diseases Society of America guidelines for the diagnosis and treatment of asymptomatic bacteriuria in adults. Clin Infect Dis 40: 643-654.

15. US Preventive Services Task Force (2008) Screening for asymptomatic bacteriuria in adults: US Preventive Services Task Force reaffirmation recommendation statement. Ann Intern Med 149: 43-47.

16. American Academy of Family Physicians Summary of Recommendations for Clinical Preventive Services. American Academy of Family Physicians, Policy Action: November 1996, Revision 6.0, August 2005: 3.

17. Gupta K, Hooton TM, Naber KG, Wullt B, Colgan R, et al. (2011) International clinical practice guidelines for the treatment of acute uncomplicated cystitis and pyelonephritis in women: A 2010 update by the Infectious Diseases Society of America and the European Society for Microbiology and Infectious Diseases. Clin Infect Dis 52: e103-e120.

18. Collee JG, Fraser AG, Marmion BP, Simmons A (2014) Mackie \& Mc Cartney Practical Medical Microbiology (14th edn)

19. Abirami K, Tiwari SC (2001) Urinalysis in Clinical Practice (Akin to Liquid Kidney Biopsy). Journal of Indian Academy of Clinical Medicine 2: 39-50.

20. Shilpa K, Bernaitis L, Mathew J, Shobha KL, Ramyasree A, et al. (2015) Comparison of urine microscopy and culture from urinary tract infection-a retrospective study. International Journal of Health Information and Medical Research 2: 12-17.

21. Khattak AM, Khan H, Akhtar W, Mahsud I, Ashiq B (2004) Accuracy of Griess test to predict asymptomatic bacteriuria during pregnancy. Gomal J Med Sci 2: 20-24.

22. Schaus R (1956) Griess' nitrite test in diagnosis of urinary infection. J Am Med Assoc 161: 528-529.

23. Ansari HQF, Rajkumari A (2011) Prevalence of asymptomatic bacteriuria and associated risk factors among antenatal women attending a tertiary care hospital. J Med Allied Sci 1: 74-78.

24. Siddiqui SM, Deshmukh AB, Afreen U, Bhanap PL (2014) Evaluation of screening tests to detect asymptomatic bacteriuria in obstretic patients at Noor Hospital, Warudi, Jalna,Maharashtra. Medpulse - Int Med J 1: 623-626.

25. Patil SS, Krishna MKS, Mariraj J, Dharwad ASK, Sathyanarayan MS (2011) Evaluation of gram stain of uncentrifuged urine as a screening method for diagnosis of urinary tract infections. Current Research in Medicine and Medical Sciences 1: 19-21.

26. Wikler MA (2007) Performance standards for antimicrobial susceptibility testing: Seventeenth informational supplement. Clinical and Laboratory Standards Institute.

27. Lee $M$, Bozzo P, Einarson A, Koren $G$ (2008) Urinary tract infections in pregnancy. Can Fam Physician 54: 853-854.

28. Jayalakshmi J, Jayaram VS (2013) Evaluation of various screening tests to detect asymptomatic bacteriuria in pregnant women. Indian J Pathol Microbiol 51: 379-381. 
29. Jennifer P, Cyril R, Piyumi P, Nimesha G, Renuka J (2012) Asymptomatic Bacteriuria in Pregnancy: Prevalence, Risk factors and Causative Organisms. Sri Lankan Journal of Infectious Diseases 1: $42-46$

30. Mokube MN, Atashili J, Halle-Ekane GE, Ikomey GM, Ndumbe PM (2013) Bacteriuria amongst pregnant women in the Buea Health District, Cameroon: prevalence, predictors, antibiotic susceptibility patterns and diagnosis. PLoS One 8: e71086.

31. Kasinathan A, Thirumal P (2014) Prevalence of asymptomatic bacteriuria in antenatal women attending a tertiary care hospital. Int J Reprod Contracept Obstet Gynecol 3: 437-441.

32. Prasanna B, Naimisha M, Swathi K, Shaik MV (2015) Prevalence of Asymptomatic Bacteriuria in Pregnant Women, Isolates and their Culture Sensitivity Pattern. Int J Curr Microbiol Appl Sci 4: 28-35.

33. Kerure SB, Surpur R, Sagarad SS, Hegadi S (2013) Asymptomatic bacteriuria among pregnant women. Int J Reprod Contracept Obstet Gynecol 2: 213-216.

34. Ajayi AB, Nwabuisi C, Aboyeji AP, Ajayi NS, Fowotade A, et al. (2012) Asymptomatic bacteriuria in antenatal patients in ilorin, Nigeria Oman Med J 27: 31-35.

35. Hamdan HZ, Ziad AHM, Ali SK, Adam I (2011) Epidemiology of urinary tract infections and antibiotics sensitivity among pregnant women at Khartoum North Hospital. Ann Clin Microbiol Antimicrob 10: 1-5.

36. Schnarr J, Smaill F (2008) Asymptomatic bacteriuria and symptomatic urinary tract infections in pregnancy. Eur J Clin Invest 38: 50-57.

37. Nicolle LE (2003) Asymptomatic bacteriuria: when to screen and when to treat. Infect Dis Clin North Am 17: 367-394.

38. Cardoso CL, Muraro CB, Siqueira VLD, Guilhermetti M (1998) Simplified Technique for Detection of Significant Bacteriuria by Microscopic Examination of Urine. J Clin Microbiol 36: 820-823.

39. Taneja N, Chatterjee SS, Singh M, Sivapriya S, Sharma M, et al. (2010) Validity of Quantitative Unspun Urine Microscopy, Dipstick
Test Leucocyte Esterase and Nitrite Tests in Rapidly Diagnosing Urinary Tract Infections. J Assoc Physicians India 58:485-487.

40. Nabbugodi WF, Gichuhi JW, Mugo NW (2015) Aetiology, and Antibiotic Sensitivity Pattern among Antenatal Women Presenting with Lower Abdominal Pains at Kenyatta National Hospital, Nairobi, Kenya. The Open Access Journal of Science and Technology 3:1-6.

41. Berger SA, Bogokowsky B, Block C (1990) Rapid screening of urine for bacteria and cells by using a catalase reagent. J Clin Microbiol 28: 1066-1067.

42. Pezzlo M (1988) Detection of urinary tract infections by rapid methods. Clin Microbiol Rev 1: 268-280.

43. Gayathree L, Shetty S, Deshpande SR, Venkatesha DT (2010) Screening for asymptomatic bacteriuria in pregnancy: An Evaluation Of Various Screening Tests At The Hassan District Hospital, India. J Clin Diagn Res 4: 2702-2706.

44. Udawat M, Nithyalakshmi J, Sumathi G, Mallure S (2014) A Study on the Prevalence of Asymptomatic Bacteriuria and their Antibiogram Pattern among Pregnant Women in a Tertiary Care Hospital. J Evol Med Dent Sci 3: 7920-7927.

45. Nithyalakshmi J (2014) Vijayalakshmi. Bacterial profile and antibiogram pattern of uti in pregnant women at tertiary care teaching hospital. Int J Pharma Bio Sci 5: 201-207.

46. Vaijanathrao CY, Nalini YL, Reddy CM (2015) Antibiotic Sensitivity Pattern of Uropathogens: A Comparative Study between Symptomatic and Asymptomaic Bacteriuria in Pregnant Women. Int J Curr Microbiol Appl Sci 4: 689-695.

47. Teshale AM, Desta K, Mulugeta G, Asamene N, Birara M, et al. (2015) Prevalence And Antibiotics Susceptibility Pattern Of Common Bacterial Uropathogens Isolated From Pregnant Women Attending Antenatal Care Clinic At St. Paul Hospital Millennium Medical College And Selam Health Center, Addis Ababa, Ethiopia 2: 1288-1305. 